\title{
ODABIR SPOLA EMBRIONA KROZ PRIZMU ŠERIJATA
}

\section{Sažetak}

Moderni stil života i savremena tehnička dostignuća inicirali su mnoga pitanja koja klasični islamski pravnici nisu razmatrali. Kur'an, posljednja Bǒ̌ija objava, i sunnet, iqreke $i$ djelo posljednjeg Poslanika, kao temeljni izvori vjere islama, direktno ili indirektno, u sebi sadrže sud o svim inovacijama i pojavama koje ce se dešavati sve do Sudnjeg dana. Izučavanjem tih pojava, s ciljem prepoznavanja šerijatskih propisa o njima, u kur'anskim ajetima i riječma Poslanika, sallallahu alejhi ve sellem, koji ne govori po hiru svome, nočava se Božanska svjetlost $i$ savršeno znanje, jer iako su izrečeni u vremenu kada je ljudsko znanje bilo na vrlo niskom nivou, u potpunom su skladu sa savremenom spoznajom i modernim naućnim otkricima.

Formiranje spola embriona, poput svega ostalog u prirodi koja nas okruそ̌uje, odvija se po ustaljenom zakonu koji je uspostavio Uqvišreni Allah. Savremeni covjek otkrio je detalje tog rakona koji su ranije ljudskoj vrsti bili nepoznati, cime se otvorila mogucnost utjecaja na spol embriona. S druge strane, vjernik dobro zna da je Uqvišeni Allah taj koji stvara $i$ odabire $i$ sve se, na početku $i$ na koncu, Njemu vraća. On je taj koji poklanja onome kome řeli mušku djecu, a onome kome želi žensku djecu, a koga želi - ostavlja bez potomstva. Stoga je odabir spola embriona pitanje koje se posmatra sa aspekta islamske doktrine - akideta, koja tretira vjerovanje $i$ ubjedenje muslimana, $i$ sa aspekta islamskog prava - fikha, koji tretira praktičnu stranu, odnosno djela i postupke.

Metode odabira spola su brojne i njihovi propisi se razlikuju, a islamski autoriteti su iznijeli svoja mišljenja o njima, kao sto će kroz ovaj rad, Allabovom dozvolom, biti prikazano. metode...

Ključne riječi: Spol, dijete, sjeme, embrion, odabir, muški, ženski,

\section{Uvod}

Odabir spola novorođenčeta je drevna želja mnogih ljudi. Još od davnina su ljekari, filozofi i mudraci postavljali razne teorije kako ostvariti tu želju. Preteče u tome bili su grčki filozofi poput Parmenida, Anaksagorija, Hipokrata i Aristotela. Jedan od najpoznatijih drevnih

${ }^{1}$ Doktorant na islamskom univerzitetu El-Imam, Rijad-Saudijska Arabija. 
načina odabira spola djeteta jeste tzv. kineska metoda. Ova metoda bazirana je na pretpostavci da spol djeteta reguliraju dva faktora: starost žene i mjesec u kojem se desi oplodnja. $\mathrm{Na}$ osnovu toga je napravljena posebna tabela poznata pod nazivom kineska tabela. Ova i druge drevne metode nemaju nikakve naučne osnove, radi se samo o pukom pretpostavljanju, nagađanju i praznovjerju.

Moderna nauka poništila je sve te teorije i zamijenila ih drugim metodama koje se baziraju na naučnim činjenicama i laboratorijskim eksperimentima. Znanstvenici su, zahvaljujući modernim otkrićima, uspjeli pomno izanalizirati i jajnu ćeliju i spermatozoide i tako otkriti mnoge njihove tajne. Otkrili su da jajna ćelija nosi samo ženske osobine (x), a svaki od miliona spermatozoida, koji se zajedno izbace, nosi ženske (x) ili muške (y) osobine, te da se jajna ćelija oplodi ulaskom jednog od tih spermatozoida u nju. Bude li to spermatozoid (koji nosi oznaku muškog spola-y), dijete biva muško, a bude li to spermatozoid (koji nosi oznaku ženskog spola-x), dijete biva žensko, dozvolom Sveznanog Stvoritelja. ${ }^{2}$

\section{Nastanak muškog i ženskog spola u opisu Poslanika, sallallahu slejhi ve sellem}

Sevban, radijallahu anhu, je rekao: „Stajao sam kod Allabovog Poslanika, sallallahu alejhi ve sellem, kad dođe jedan jevrejski učenjak te kara: „Esselamu alejke, Muhammede... Došao sam da te pitam o djetetu!" Poslanik, sallallahu alejhi ve sellem, rě̌e: „Voda muškarca je bijela, a voda žene je ̌̌uta, pa kada se sastanu, te sjeme muškarca nadvlada sjeme žene, od ta dva sjemena će, uz. Allahovu dozvolu, nastati muškoo, a kada žensko sjeme nadvlada muško sjeme, od ta dva sjemena će, uz. Allabovu dozvolu, nastati žensko. “3

Ranije se vjerovalo da je isključivo žena odgovorna za spol novorođenčeta, ili da je za to odgovoran isključivo muškarac, a da žena rađa samo ono što se u nju "posije", dok se iz ovog hadisa razumije da u formiranju muškog ili ženskog spola učestvuju muškarac i žena zajedno i da nastanak spola ovisi od toga čija voda (sjeme) će nadvladati. Kako

2 Pogledati: El-Mevsuatul-arebijjetul-alemijje (Arapska svjetska enciklopedija), termin: ettekasurul-bešeri/el-ihsab (ljudsko razmnožavanje/oplodnja), 7/95, i dr. Muhammed elBar, Halkul-insani bejnet-tibbi vel-Kur'ani, str. 297, Darus-Saudije, Džidda, sedmo izdanje, 1409. h.g.

${ }^{3}$ Bilježi Muslim, knjiga: Hajd, poglavlje: Osobine muškog $i$ ženskog sjemena $i$ da se dijete stvara od oba sjemena, br. 315 . 
izgleda to nadvladavanje, najbolje zna Uzvišeni Allah, međutim, postoje pokušaji da se na osnovu najmodernijih naučnih otkrića pojasni suština tog nadvladavanja.

Naučno je poznato da se ljudsko tijelo sastoji od stotine biliona živih ćelija. Svaka od tih ćelija sadrži 46 kromosoma sastavljenih od 23 para, a samo jedan od njih je odgovoran za odredivanje spola embriona. Spolne ćelije imaju polovičan broj hromosoma (23), što je prilagodba za održavanje karakterističnog diploidnog broja nakon oplodnje. Od ukupno 46 hromosoma u čovjeka, 44 su autosomi, a preostala dva su heterohromosomi (spolni hromosomi ili gonosomi) koji određuju spol osobe: x i y (kombinacija xx za ženski, a xy za muški spol). Kod žena, sve jajne ćelije koje se nalaze u jajnicima su identične, tako da se svaka od njih sastoji od 22 hromosoma + dodatni ženski hromosom koji se označava sa x tj. $(22+\mathrm{x})$. Dok se kod muškaraca, $\mathrm{u}$ testisima, nalaze spermatozoidi kojih ima dvije vrste, pola njih su sa hromosomom tipa $\mathrm{x}$, koji nose oznaku ženskog spola, tj. $(22+\mathrm{x})$, a druga polovina su tipa y, koji nose oznaku muškog spola, tj. $(22+$ y). Kada se spermatozoid sa hromosomom tipa y, koji nosi oznaku muškog spola $(22+$ y) spoji sa jajnom ćelijom, embrion biva muški, tj. dvadeset i treći par hromosoma nosi oznaku xy, a kada se spermatozoid sa hromosomom tipa x, koji nosi oznaku ženskog spola $(22+\mathrm{x})$ spoji sa jajnom ćelijom, embrion, Allahovom dozvolom, biva ženski, tj. dvadeset i treći par hromosoma nosi oznaku xx. ${ }^{4}$

Dakle, muško sjeme nosi muški i ženski spol, a to se može razumjeti iz riječi Uzvišenog Allaha: „I da On par, muško i žensko, stvara od kapi sjemena kad se izbaci. “(En-Nedžm, 45-46)

Međutim, od čega ovisi da li će jajna ćelija prihvatiti spermatozoid tipa $\mathrm{x}$ ili tipa $\mathrm{y}$ ??

Moderna znanost otkrila je da membrana jajne ćelije posjeduje elektronaboj i da taj naboj nije fiksan, nego se mijenja, tako da biva pozitivan, neutralan i negativan, u ciklusu koji je nazvan polarni ciklus membrane jajne ćelije (The polarity cycle of the ovum membrane) i taj naboj moguće je predvidjeti. U vremenu kada membrana poprimi

4 Pogledati: El-Mevsuatul-arebijjetul-alemijje (Arapska svjetska enciklopedija), termin: ettekasurul-bešeri/el-ihsab (ljudsko razmnožavanje/oplodnja), 7/95, i Nasir el-Mejmani, En-Nevažilut-tibbijje, str. 127, Daru-ibnul-Dževzi, prvo izdanje, 1430. h.g., Demam, Saudijska Arabija. 
pozitivni naboj, privući će spermatozoid x (koji nosi oznaku ženskog spola) koji nosi negativni naboj i nastat će ženski embrion. U vremenu kada membrana poprimi negativni naboj, privući će spermatozoid y (koji nosi oznaku muškog spola) i, Allahovom dozvolom, nastat će muško dijete. $^{5}$

$\mathrm{Na}$ osnovu otkrića spermatozoida sa hromosomima tipa y (koji nose oznaku muškog spola) i tipa x (koji nose oznaku ženskog spola) zavladalo je mišljenje da je isključivo muškarac odgovoran za nastajanje muškog ili ženskog spola, te da žena u tome nema nikakve uloge, dok se iz Poslanikovih riječi dalo naslutiti da tu odgovornost nose muškarac i žena zajedno. Tako naprimjer, u spomenutom hadisu Sevbana, radijallahu anhu, Poslanik, sallallahu alejhi ve sellem, spominje međusobno nadvladavanje muškog i ženskog sjemena, te da je nadvladavanje jednog od dva sjemena uzrok da dijete poprimi spol roditelja čije je sjeme nadvladalo. Ukoliko su ova naučna otkrića tačna, moguće je da se "nadvladavanje" odnosi na pozitivni naboj, jer pozitivni naboj je superiorniji od negativnog, zbog daleko veće težine protona koji nosi pozitivni naboj od elektrona koji nosi negativni naboj. Primijeni li se to na proces oplodnje, uočit ćemo da jajna ćelija po primitku negativnog naboja privlači spermatozoid tipa y, pozitivnog naboja, sa oznakama muškog spola i time nadvladavanje biva na strani spermatozoida, jer je pozitivnog naboja u odnosu na jajnu ćeliju koja je tada negativnog naboja - tada nastaje muško dijete. $\mathrm{Na}$ to aludiraju riječi iz hadisa: „,...) pa kada se sastanu te sjeme muškarca nadvlada sjeme žene, od ta dva sjemena će, ur. Allahovu dozvolu, nastati musko. Kada jajna ćelija poprimi pozitivni naboj, privući će spermatozoid tipa x koji nosi negativni naboj i oznake ženskog spola, a time će žensko sjeme nadvladati muško: (...) a kada そ̌ensko sjeme nadvlada muško sjeme, od ta dva sjemena će, uz. Allahovu dozvolu, nastati žensko. "

Drugi način savremenog tumačenja "nadvladavanja" spomenutog u hadisu jeste da je tekućina muškarca lužasta (alkalna), a tekućina žene kisela. Kada se dvije "vode" sastanu, te ženska tekućina nadvlada mušku, nastaje kisela sredina koja otežava kretanje spermatozoida koji nose muške osobine, a spermatozoidima koji nose ženske osobine odgovara

5 Babychoice / Selnas Method, Baby choice Hong Kong, www.babychoice.hk /Method.html. Pogledati članak pod naslovom: "Ko je odgovoran za određivanje spola embriona?", dr. Džemal Hamid, El-I'adžazul-ilmij, br. 29, str. 8, izdavač: Svjetski kolegij za naučne mudžize (nadnaravnost) u Kur'anu i sunnetu, safer1429. h.g.

${ }^{6}$ Ibid., str. 9. 
takva kisela sredina, te uspijevaju proći do jajne ćelije i oploditi je i tako nastane žensko dijete. U suprotnom slučaju, kada muška tekućina nadvlada žensku, sredina postaje lužasta, što onemogućava kretanje spermatozoida koji nose ženske osobine, a omogućava spermatozoidima koji nose muške osobine dolazak do jajne ćelije koju oplođavaju i tako nastaje muško dijete. ${ }^{7}$ Postoje i druga moderna tumačenja hadisa, a Svemogući Allah najbolje zna. ${ }^{8}$

Uzvišeni Allah u časnom Kur'anu, kao i Njegov Poslanik, sallallahu alejhi ve sellem, u svom sunnetu, obraća se jezikom koji je svijet u vrijeme objave mogao razumjeti, ali su, istovremeno ti izrazi toliko precizno izrečeni da ostaju stalno čudo, jer se razvojem nauke i novim otkrićima mogu razumijevati pojedinosti kakve su u ranije vrijeme bile nedokučive. Rekao je Uzvišeni Allah: Mi ćmo im pružati doką̧e Naše u prostranstvima svemirskim, a i u njima samim, dok im ne bude sasvim jasno da je Kur'an istina. A zar nije dovoljno to što je Gospodar tvoj o svemu obavijesten? (ElFussilet, 53)

\section{Metode odabira spola djeteta}

Znanstvenici su istražili osobine spermatozoida tipa y $\mathrm{i} x$, te su uočili razlike među njima, od kojih su najistaknutije:

- Spermatozoid tipa y se brže kreće od spermatozoida tipa x, te stiže do jajne ćelije otprilike za šest sati, dok onaj tipa x stiže za 12 ili više sati,

- Spermatozoid tipa y kraće živi od spermatozoida tipa x,

- Spermatozoid tipa y teži lužastoj sredini, dok spermatozoid tipa $\mathrm{x}$ teži kiseloj sredini,

- Spermatozoid tipa y je blještav za razliku od spermatozoid tipa x.

Ova otkrića su imala suštinski utjecaj na određivanje metoda odabira spola u modernom vremenu, jer se te metode u osnovi baziraju na omogućavanju da spermatozoid željenog tipa dođe do jajne ćelije i oplodi je. Najpoznatije metode odabira spola novorođenčeta su slijedeće:

\footnotetext{
${ }^{7}$ Ibid., str. 10 .

8 Ibid., str. 8-12.
} 


\section{Vremensko reguliranje snošaja}

Ova metoda je poznata kao Šetlesova metoda. To je jedna od prirodnih metoda odabira spola novorođenčeta, jer se oslanja na fizičke osobine spermatozoida. Već smo vidjeli da su spermatozoidi y pokretljiviji, brži i da kraće žive u odnosu na one tipa x. To znači da, što odnos bude bliži ovulaciji, vremenu oslobađanja jajne ćelije, koja se kod 28-dnevnog ciklusa događa 14 dana poslije početka menstruacije, prilika spajanja spermatozoida y (sa oznakama muškog spola) sa jajnom ćelijom biva veća i time raste mogućnost začeća muškog djeteta. Veća mogućnost začeća ženskog djeteta biva kada se odnos desi dva ili tri dana pred ovulaciju. Šetles tvrdi da se procent uspješnosti ove metode kreće od $79 \%$ do $90 \%$.

\section{Jelovnik ili prehrambena metoda}

Jedna od prirodnih metoda odabira spola djeteta realizira se konzumiranjem određenih vrsta hrane. Rezime ideje na kojoj je bazirana ova metoda jeste da povećanje procenta sodijuma i kalijuma, uz smanjenje procenta kalcija i magnezija, uzrokuje promjene na membrani jajne ćelije tako da privlači spermatozoide tipa y koji nose oznake muškog spola, a odvraća spermatozoide tipa x koji nose oznake ženskog spola. Suprotno tome će rezultirati privlačenjem spermatozoida tipa x, a odbijanjem onih tipa y. Žena koja želi da zanese muško dijete treba što više jesti hranu bogatu sodijumom i kalijumom, a žena koja želi žensko dijete treba da što više jede hranu bogatu kalcijem i magnezijem i da smanji konzumiranje hrane bogate sodijumom i kalijumom. Ljekari su za to napravili određenu tabelu koje se žena pridržava kroz period od najmanje tri mjeseca. Većina onih koji su pisali o ovoj metodi ukazuju da je uspješna, iako postoje medicinari koji smatraju da ova metoda ne koristi i ne daje rezultate.

3. Ispiranje ulaza u maternicu s ciljem da sredina postane kiselasta ili lužasta

Rezime ove metode jeste da kisela sredina više odgovara ženskim spermatozoidima, te da lužasta sredina više odgovara spermatozoidima tipa y. Žena koja želi muško ili žensko dijete, prema ovoj metodi, će isprati spolni organ tekućinom koja će utjecati na jačanje kiselog ili lužastog stanja. Neki medicinari su potvrdili uspjeh ove metode, iako u niskim procentima, dok drugi ljekari tvrde da ova metoda nema utjecaja u formiranju spola djeteta. 


\section{Oplodnja po odabiru}

Najprije se odvoje spermatozoidi tipa y sa oznakom muškog spola od spermatozoida tipa x sa oznakom ženskog spola, a zatim se željeni tip spermatozoida ubrizga u maternicu da se sastanu sa jajnom ćelijom. Medicinari tvrde da je ova metoda uspješna do $98 \%$.

5. Dijete iz epruvete

Bazira se na tome da se ispita spol djeteta nakon što se oplodnja desi van maternice, a zatim se željeni spol unese u maternicu. Ostale oplođene jajne ćelije se uklone.

6. Odabir spola abortusom

Ova metoda se bazira na saznanju spola embriona u maternici te abortiranju neželjenog spola. ${ }^{9}$

Ove metode se razlikuju u procentu uspjeha, međutim, stvar u koju nema sumnje jeste da je sada, uz Allahovu dozvolu, moguće utjecati na spol embriona. Međutim, pitanje koje se samo nameće jeste: „Koliko je to šerijatski dozvoljeno"?

\section{Odabir spola djeteta kroz prizmu islamskog akaida (doktrine)}

Odabir spola djeteta je pitanje koje se veže za akidet - vjerovanje muslimana, s jedne strane, i za fikh - islamsko pravo, s druge strane. Sve što je sporno sa akaidske strane, definitivno je sporno i sa fikhske, stoga ćemo prvo razmotriti akaidsku stranu ovog pitanja.

$\mathrm{Na}$ prvi pogled se može steći utisak da je odabir spola djeteta u kontradiktornosti sa islamskom akidom, a to se vraća na dvije postavke: vjerovanje da su stadiji razvoja embriona i njegov spol gajb koji zna samo Uzvišeni Allah i vjerovanje da je određivanje spola djeteta vid uplitanja $u$ volju Uzvišenog Allaha, o čemu slijedi detaljniji govor.

\section{Prvo: Da li je spol embriona u utrobi majke od stvari gajba koje niko osim Allaha ne može znati?}

Uzvišeni Allah kazao je: Samo Allah zna kad ce Smak svijeta nastupiti, samo On spusta kišu i samo On zna šta je u maternicama, a covjek ne zna šta će

${ }_{9}^{9}$ Pogledati: Nasir el-Mejman, En-Nevarilut-tibbijje, str. 131-133. 
sutra zaraditi i ne zna covjek u kojoj će zemlji umrijeti; Allah, wistinu, sve zna i o svemu je obaviješten. (Lukman, 34)

Ovih pet stvari, Poslanik, sallallahu alejhi ve sellem, nazvao je ključevima gajba, rekavši: Pet je ključeva gajba: samo Allab zna kad će Smak svijeta nastupiti, samo On spušta kišu i samo On zna šta je u maternicama... ${ }^{10}$

Allahovo znanje o onome šta je u maternicama je precizno znanje o svim detaljima koji se tiču embriona, njegovim fizičkim, moralnim, urođenim i stečenim osobinama, te šta će mu se desiti u budućnosti. Allah zna sve o njemu, prije njegovog stvaranja, od trenutka kada je bio kap neznatne tekućine, zatim novorođenče i sve do njegove smrti, kao i nakon smrti na ahiretu. Uzvišeni Allah obavještava da je ovakvo univerzalno znanje svojstveno samo Njemu, a to ne negira mogućnost spoznaje određenih detalja vezanih za embrion, kao što je njegov spol. Tako su ajet, još prije modernih otkrića, shvatili klasični islamski učenjaci. Ilustracije radi navest ću nekoliko primjera:

Ibn $\operatorname{Kesir}^{11}$ u komentaru spomenutog ajeta kaže: „Isto tako, niko osim Njega ne zna šta je u maternicama - tj. šta Allah želi da u njima stvori - ali kada On naredi da dijete bude muško ili řensko, ili pak nesretan ili sretan, onda to saznaju i meleki koji su za to zaduæ̌eni kao i neka Njegova druga stvorenja kojima je on to dozvolio". 12

Imam El-Kurtubi ${ }^{13}$ zaključio je da se ajetom ustvari žele opovrgnuti tvrdnje vračara, proroka i njima sličnih koji o tome govore, a ne oslanjaju se na stvarne uzroke $\mathrm{i}$ iskustva. On je u vezi s ovim ajetom rekao: „Cilj je poništiti govore vračara, proroka i onih koji od zvijezda trǎ̌e kišu, a možda se dugotrajnim iskustvom mogu ₹nati stvari poput muškog ili ženskog spola djeteta u stomaku, kao sto je ranije rečeno u suri El-En'am, ipak ponekad to iskustvo može i qakazati, a pravo znanje ostaje jedino kod Allaha“. ${ }^{14}$

\footnotetext{
${ }^{10}$ Buharija, knjiga: Tefsir, poglavlje: Kod Njega su ključevi gajba, niko ih osim Njega ne zna, br. 4627.

11 Ebul-Feda Ismail bin Omer bin Kesir, umro 774. h.g. / 1372. g.

12 Ebul-Feda Ismail bin Omer ibn Kesir, Tefsirul-Kur'anil-'azim, 3/462, obrada: Sami bin Muhammed Selame, Daru Taibe lin-nešri vet-tevzi, drugo izdanje, 1420. h.g.

${ }^{13}$ Ebu Abdullah Muhammed ibn Ahmed el-Kurtubi, umro 671. h.g. / 1272. g.

14 Ebu Abdullah Muhammed bin Ahmed el-Kurtubi, El-Dæ̌ami'u li abkamil-Kur'ani, 14/82, Darul-kutubil-misrije, drugo izdanje, Kairo, 1384. h.g.
} 
El-Maverdi ${ }^{15}$ konstatira da se Allahove riječi: (...) i samo On zna šta je u maternicama..., mogu odnositi na dvije stvari:

- da samo On zna da li je dijete u maternici muškog ili ženskog spola i da li će biti zdravo ili bolesno;

- da samo On zna da li je dijete u maternici vjernik ili nevjernik, sretan ili nesretan. ${ }^{16}$

Uzvišeni Allah nije rekao da spol djeteta u utrobi majke ne zna niko osim Njega, niti da to niko osim Njega neće znati, a to nije kazao ni Poslanik, sallallahu alejhi ve sellem, nego je u komentarima Kur'ana kao primjer znanja o onome što je u maternicama navođen spol djeteta, jer je to prvo što pada na pamet u vezi s embrionom, a nema sumnje da je znanje o spolu djeteta u tom vremenu ljudima bilo nedokučivo. Danas kada je to muguće, zna se da to ne spada u "ključeve gajba" koje zna samo Uzvišeni Allah, jer ono što samo Allah zna niko drugi ne može ni znati ${ }^{17}$. Ajet se odnosi na potpuno znanje o onom što je u maternicama, a ne na puku spoznaju spola, kao što je u drugom ajetu Uzvišeni Allah rekao: U Njega su ključevi svih tajni, samo ih On zna, i On jedini żna šta je na kopnu $i$ sta je u moru, i nijedan list ne opadne, a da On za nj ne zna... (El-En'am, 59), čime se ne negira mogućnost da čovjek spozna nešto od onoga što je na kopnu i šta je u moru ili da zna kada neki od listova opadne.

Znanje spola djeteta u utrobi majke je poput ostalih tajni Allahovog stvaranja, koje je Allah omogućio ljudima da ih spoznaju, a u njima su, za razumom obdarene, jasni znakovi Allahove moći i beskrajne mudrosti.

\section{Drugo: Da li je odabir spola djeteta u kontradikciji sa Allahovom voljom?}

Svevišnji Allah kazao je: Allahova je vlast na nebesima i na Zemlji. On stvara šta hoće! On poklanja žensku djecu kome hoće, a kome hoće - mušku, ili im daje $i$ mušku $i$ žensku, a koga hoće, učini ber poroda; On uistinu, sva zna $i$ sve

\footnotetext{
${ }^{15}$ Ebul-Hasan bin Muhammed el-Maverdi, umro 450. h.g. / 1058. g.

16 Ebul-Hasan bin Muhammed el-Maverdi, En-Nuketu vel-'ujun, 3/330, Darul-kutubililmije, Bejrut-Libanon, obrada: Es-Seid ibn Abdul-Maksud.

17 Abbas el-Baz, elaborat pod naslovom: Ibtijaru ď̌insil-mevludi ve tahdidubu kable tehallukibi ve viladetibi bejnet-tibbi vel-fikh, zbirka elaborata: Dirasatun fikhijetun fi kadaja tibbijje muasire, 2/867, Darun-nefais, Jordan, prvo izdanje, 1421. h.g. i prof. dr. Nasir elMejman, En-Nevarilut-tibbijje, str. 139.
} 
može. (Eš-Šura, 49-50) Musliman čvrsto vjeruje da je Allah taj koji poklanja djecu kakvu želi i kome želi. Vjeruje da Uzvišeni Allah radi šta On hoće, u Njegovoj vlasti se dešava samo ono što On želi, prema tome nikako nije dopušteno zamisliti da je moguće stvorenju da se umiješa u volju Stvoritelja. Sve što se dešava na svijetu biva Allahovim znanjem i Njegovom univerzalnom voljom. Čovjekov utjecaj u izboru spola djeteta ne izlazi iz ovog pravila. Sve što čovjek čini na tom polju biva Allahovom voljom i znanjem i u krugu uzroka na kojima je uspostavljen život: "A vi ćete btjeti samo ono sto Allah hoće - Allah, uistinu, sve zna i mudar je." (EdDehr, 30) Allah je taj koji je omogućio čovjeku da dokuči ono što On hoće od znanja i niko ne može izaći iz kruga Allahovog htijenja i Njegove odredbe. U tom značenju su riječi Omera, radijallahu anhu, kada je odlučio da ne uđe u zemlju u kojoj je zavladala kuga, nakon što mu je prigovoreno riječima: „Da li to bježiš od Allahove odredbe“?, na što je on kazao: „Da, bježimo od Allahove odredbe Allahovoj odredbi." 18

Radi se o uzroku poput ostalih uzroka, koji kada se učine, Allahovom voljom, daju rezultate, jer Allah je za određivanje spola djeteta učinio da postoje prirodni uzroci, kao što je na to Poslanik, sallallahu alejhi ve sellem, ukazao u spomenutom hadisu Sevbana, radijallahu anhu: „Voda muškarca je bijela, a voda žene je そ̌uta, pa kada se sastanu, te sjeme muškarca nadvlada sjeme žene, od ta dva sjemena će, uz. Allahovu dozvolu, nastati muško, a kada žensko sjeme nadvlada muško sjeme, od ta dva sjemena cé, uz. Allahovn dozvolu, nastati žensko". Bez imalo sumnje, Poslanikove riječi, uz. Allahovu dozvolu, ne negiraju ulogu uzroka spomenutog u hadisu. Isto tako, sreća, nesreća, opskrba i sl. su vezane za Allahovu odredbu, a dešavaju se određenim uzrocima. Sve što se čini, pokušaj je ostvarenja potrebnih uzroka, zatim ako Allah hoće, učinit će da daju rezultat, a ako hoće, učinit će ih beskorisnim. Stvar je na početku i na kraju u Allahovoj ruci.

Prema tome, izbor spola djeteta nije u oprečnosti sa islamskim vjerovanjem i nije kontradiktoran svetim tekstovima. Preostaje da vidimo kakav je fikhski propis odabira spola djeteta.

18 Buharija, knjiga: Medicina, poglavlje: Predaje o kugi, br. 5397, i Muslim, Knjiga o selamu, poglavlje: Kuga i sujevjerje, br. 2219. 


\section{Odabir spola djeteta kroz prizmu islamskog prava}

Suvišno je reći da je pitanje odabira spola djeteta jedno od modernih pitanja o kojem nije došao izravan kur'anski ili hadiski tekst koji bi to zabranio ili dozvolio, niti su raniji učenjaci izučavali to pitanje. Ovo pitanje je isprepleteno, jer se vraća na više pravila, tiče se akide i fikha, pojedinca i zajednice, te se u njemu odmjeravaju koristi i štete, a metode odabira spola djeteta u pogledu Šerijata nisu istovjetne, neke od njih su same po sebi dozvoljene, a to su prirodni putevi, a druge su neostvarive bez činjenja zabranjenog djela, kao što je otkrivanje stidnog mjesta, ili bojazni da se pomiješa sjeme i tako izmijeni porijeklo, poput laboratorijskih metoda.

$\mathrm{S}$ te strane, istraživanje ovog pitanja mora biti temeljno i obuhvatno, u svjetlu parcijalnih dokaza, pravila, ciljeva i intencija Šerijata, a uzimanjem u obzir opće koristi Allahovih robova u sadašnjosti i budućnosti.

Mišljenja modernih učenjaka po ovom pitanju su raznolika. Neki su to zabranili, mnogi dozvolili, uz određene uvjete i pravila, neki su ostali suzdržani, a neki su napravili razliku shodno metodama i stanjima.

Prvo mišljenje: Većina učenjaka je mišljenja da je odabir spola djeteta - ukoliko se ispune precizni uvjeti koji ograničavaju to djelo i smanjuju domenu njegove primjene - dozvoljen. Najistaknutiji pobornici ovog mišljenja su: dr. Jusuf el-Karadavi ${ }^{19}$, prof. dr. Muhammed Osman Šbejr ${ }^{20}$, dr. Muhammed Re'fe Osman i drugi. ${ }^{21}$

Drugo mišljenje: Odabir spola djeteta je zabranjen. Ovo je mišljenje nekih učenjaka poput Abdurrahmana Abdul-Halika ${ }^{22}$, a također

19 Dozvolu je ograničio na stanje prijeke potrebe (darure) ili velike potrebe, koja poprima propis darure, a preporučio je ostavljanje pokušaja odabira spola i potpuno oslanjanje na Allahovu volju. Jusuf el-Karadavi, Fetava mu'asire, 1/575, Darul-Kalemi, Kuvajt, četvrto izdanje, 1424. h.g. Preuzeto iz: Nasir el-Mejmani, En-Nevazilut-tibbijje, str. 151.

20 Muhammed Osman Šubejr, elaborat pod naslovom: Mevkiful-islami minel-emradilvirasijjeti, zbirka elaborata: Dirasatun fikehijetun fi kadaja tibbijje muasire, 1/339-340.

21 Nasir el-Mejmani, En-Nevarilut-tibbijje, str. 151-153.

22 Nedvetul-indžabi fi davil-islami, 110. Preuzeto iz: Nasir el-Mejmani, En-Nevarilut-tibbijje, str. 153. 
iz fetvi Stalne komisije za fetve u Saudijskoj Arabiji razumije se zabrana ovog postupka. ${ }^{23}$

Treće mišljenje: Prirodne metode, koje ne iziskuju otkrivanje avreta pred stranim licima i druge Šerijatom zabranjene radnje, su dozvoljene, za razliku od drugih metoda. Ovo mišljenje zastupa dr. Abdullah ibn Bih i drugi. ${ }^{24}$

\section{Dokazi dozvole odabira spola djeteta i opaske na njih}

\section{Prvi dokaz:}

Dozvoljeno je doviti Allahu da podari dijete određenog spola, kao što su dovili Allahovi poslanici, a oni u dovi nisu tražili ono što je zabranjeno. Zekerija, a.s., dovio je Allahu riječima: „Bojim se rođaka svojih po krvi poslije mene, a žena mi je nerotkinja, zato mi pokloni od Sebe sina, da naslijedi mene $i$ porodicu Jakubovu, i ucini, Gospodaru moj, da budeš s njim zadovoljan." (Merjem, 5-6) Ovaj ajet jasno ukazuje da je dozvoljeno i propisano upućivati Uzvišenom Allahu dovu kojom se traži određeni spol djeteta, jer je Zekerija, a.s., dovio tražeći sina sa kojim je Allah zadovoljan, te, ako je dozvoljeno dovom tražiti dijete određenog spola, dozvoljeno je to činiti i drugim sredstvima. ${ }^{25}$

Ovom argumentu se može prigovoriti opaskom da u upućivanju dove Allahu nema opasnosti oslanjanja na druge uzroke, kao što je u slučaju kada se dijete određenog spola želi dobiti nekom od ranije spomenutih metoda. Dovom se izravno traži od Uzvišenog Allaha, čime se potvrđuje vjera u Njegovu moć i vlast, dok u primjeni drugih uzroka postoji opasnost da se osloni na te uzroke i zaboravi Onaj koji čini da uzroci daju svoje rezultate - Svemogući Allah.

$\mathrm{Na}$ ovu opasku, može se replicirati konstatacijom da su te metode samo pokušaj da se ostvari nešto što je dozvoljeno. One su poput ostalih uzroka i sredstava, kojima se čovjek služi, a rezultat je u Allahovoj ruci.

${ }^{23}$ Fetava El-Led:̌netid-daime, el-medžmuatul-ula, 2/171, fetva br. 1552, i el-medžmuatussanije, 2/14, fetva br. 19458.

24 Abdur-Rešid Kasim, Ihtijaru ď̌insil-ď̌enin diraseten fikhije tibbijje, str. 59-60. Preuzeto iz: Nasir el-Mejmani, En-Nevazilut-tibbijje, str. 154.

25 Muhammed Osman Šubejr, Mevkiful-islami minel-emradil-virasijjeti, zbirka elaborata: Dirasatun fikbijetun fi kadaja tibbijje muasire, 1/339 i Nasir el-Mejmani, En-Nevaziluttibbijje, str. 156. 
Već je ranije naveden hadis Sevbana: „Voda muškarca je bijela, a voda そ̌ene je žnta, pa kada se sastanu te sjeme muškarca nadvlada sjeme žene, od ta dva sjemena će, uz. Allabovu dozvolu, nastati muško, a kada žensko sjeme nadvlada muško sjeme, od ta dva sjemena će, ur. Allabovu dozvolu, nastati žensko", što znači da muški ili ženski spol djeteta imaju prirodne uzroke, a sve što se čini tim metodama je ostvarenje tih uzroka. ${ }^{26}$

\section{Drugi dokaz:}

Analogno dozvoli kontracepcije, dozvoljava se i odabir spola. Islamski pravnici potvrdili su dozvolu az̧a (izlučivanja sjemena izvan rodnice radi sprečavanja trudnoće) uz pristanak žene ${ }^{27}$, te kao što je dozvoljeno reguliranje same trudnoće, dozvoljen je i odabir spola djeteta određenim metodama. ${ }^{28}$

\section{Treći dokaz:}

Osnova u svemu je dozvola, sve dok ne dođe dokaz koji potvrđuje suprotno $^{29}$, a u našem pitanju nema takvog dokaza, jer određivanje spola ne vodi haramu, niti se ostvaruje putem harama. ${ }^{30}$

Ovom argumentu može se prigovoriti opaskom da laboratorijske metode sadrže harame poput otkrivanja avreta i opasnosti da dođe do miješanja sjemena i time greške u pripisivanju porijekla i očinstva.

\section{Četvrti dokaz:}

Pravilo: Šteta se otklanja ${ }^{31}$ i pravilo o otklanjanju poteškoća u vjeri utemeljeno riječima Uzvišenog Allaha: „I u vjeri vam nije ništa teško

26 Abbas el-Baz, elaborat pod naslovom: Ibtijaru ď̌insil-mevludi, zbirka elaborata: Dirasatun fikhijetun fi kadaja tibbijje muasire, 2/875, i Nasir el-Mejmani, En-Nevarilut-tibbijje, str. 156.

${ }_{27}$ El-Mevsuatul-fikhijetul-Kuvejtije, 30/81, izdavač: Ministarstvo vakufa i vjerskih pitanja, Kuvajt, 1404. - 1407. h.g.

${ }_{28}$ Abdur-Rešid Kasim, Ibtijaru ď̌insil-ď̌enin diraseten fikhije tibbijje, str. 67-68. Preuzeto iz: Nasir el-Mejmani, En-Nevazilut-tibbijje, str. 156.

29 Zejnul-abidin ibn Nudžejm, El-Ešbabu ven-nezair, str. 66, Darul-kutubil-ilmije, Libanon, 1980. g. i Abdurrahman ibn Ebi Bekr es-Sujuti, El-Ešbahu ven-nezair, str. 133, Darul-kutubil-ilmije, Libanon, prvo izdanje, 1983.

30 Abbas el-Baz, elaborat pod naslovom: Ibtijaru džinsil-mevludi, zbirka elaborata: Dirasatun fikhijetun fi kadaja tibbijje muasire, 2/875, i Nasir el-Mejmani, En-Nevarilut-tibbijje, str. 157. 
propisa“" (El-Hadždž, 78), dokaz su u ovom pitanju, jer žena koja rađa samo djecu jednog spola može neopravdano i potpuno neosnovano biti izložena neugodnostima od strane muža, kao što može doći i do razvoda braka, a može se desiti da djeca jednog spola bivaju izložena bolesti za razliku od drugog, pa je potrebno odrediti spol kako ne bi došlo do bolesti. $^{32}$

\section{Dokazi zabrane odabira spola djeteta i opaske na njih}

\section{Prvi dokaz:}

Riječi Uzvišenog Allaha: „Allahova je vlast na nebesima i na Zemlji. On stvara šta hoće! On poklanja řensku djecu kome hoće, a kome hoće - mušku, ili im daje $i$ mušku $i$ ženskeu, a koga hoće, učini bez poroda; On uistinu, sva zna i sve može. " (Eš-Šura, 49-50) Ajet upućuje na to da se odabir spola vraća isključivo Uzvišenom Allahu, pa je, prema tome, ovo akaidsko pitanje, a odabir spola djeteta je uplitanje u Allahovu volju i odredbu. ${ }^{33}$

Već je ranije bilo govora o prividnoj oprečnosti ovog ajeta i današnje stvarnosti, glede mogućnosti odabira spola djeteta, te da odabir spola djeteta nije u kontradiktornosti sa ajetom.

\section{Drugi dokaz:}

U ovim metodama je vid mijenjanja Allahovog stvaranja i njegovog preusmjeravanja. Potrebno je to ostaviti da teče svojim tokom bez uplitanja, jer Allah stvara shodno Svojoj velikoj mudrosti, koju mi ne možemo uvijek dokučiti. ${ }^{34}$

$\mathrm{Na}$ ovaj dokaz se može odgovoriti da se ove metode ne smatraju mijenjanjem Allahovog stvaranja, jer mijenjanje se dešava nakon postajanja, ne prije, a ovdje se radi samo o pokušaju da se određeni tip

31 Zejnul-abidin ibnu Nudžejm, El-Ešbahu ven-nezair, str. 85, i Abdurrahman ibn Ebi Bekr es-Sujuti, El-Ešbabu ven-nezair, str. 172.

32 Abdur-Rešid Kasim, Ibtijaru ď̌insil-dženin diraseten fikbije tibbijje, str. 68-69. Preuzeto iz: Nasir el-Mejmani, En-Nevazilut-tibbijje, str. 157.

33 Nedvetul-indžabi fi davil-islami, str. 110-111. Preuzeto iz: Nasir el-Mejmani, En-Nevaziluttibbijje, str. 159.

34 Nedvetul-indžabi fi davil-islami, str. 111, iz riječi šejha Abdurrahmana Abdul-Halika. Preuzeto iz: Nasir el-Mejmani, En-Nevąilut-tibbijje, str. 159. 
spermatozoida sastane sa jajnom ćelijom i to prije stvaranja embriona $i$ njegovog formiranja. ${ }^{35}$

\section{Treći dokaz:}

Omogućavanje odabira spola djeteta rezultira poremećajem u omjeru muškaraca i žena, što opet uzrokuje mnoge probleme na raznim poljima ljudskog života. Praktičan primjer je Kina koja je ograničila porod na jedno dijete, što je učinilo da mnoge žene abortiraju kada saznaju da nose žensko dijete iz želje za muškim djetetom, a to je dovelo do povećanja procenta muškaraca, te sada kineske vlasti predlažu zabranu otkrivanja spola djeteta u utrobi majke. ${ }^{36}$

\section{Četvrti dokaz:}

To indirektno vodi smanjenju broja članova ljudske zajednice, jer će se zadovoljiti brojem rođene djece nakon što se dobije željeni spol, a to je suprotno islamskoj uputi i poticaju na povećanje poroda i broja djece. $^{37}$

$\mathrm{Na}$ ovaj i prethodni dokaz može se odgovoriti da bi tako bilo, ako bi se odabir spola omogućio svima bez kontrole i pravila. Međutim, to nije dozvoljeno, nego je dozvola uvjetovana prijekom potrebom i svedena je na samo određena stanja. ${ }^{38}$

\section{Peti dokaz:}

Primjena ovih metoda vodi poigravanju sa očinstvom i porijeklom, a islam baštini čuvanje porijekla i krvne veze. Eventualno miješanje porijekla uzrokuje nered, koji se ne može tolerirati, radi ostvarenja puke želje roditelja. ${ }^{39}$

35 Nedvetul-indžabi fi davil-islami, riječi dr. Omera el-Eškara, str. 103. Preuzeto iz: Nasir elMejmani, En-Nevazilut-tibbijje, str. 161.

36 Objavljeno u članaku pod naslovom: "Kineski zakonodavaci pozivaju da se odrede stroge kazne za otkrivanje spola embriona", 1. 3. 2005. g. na www.china.cn. Preuzeto iz: Nasir el-Mejmani, En-Nevazilut-tibbijje, str. 160.

37 Abbas el-Baz, elaborat pod naslovom: Ihtijaru dřinsil-mevludi, zbirka elaborata: Dirasatun fikbijetun fi kadaja tibbijje muasire, 872-873.

38 Nasir el-Mejmani, En-Nevazilut-tibbijje, str. 162.

39 Nedvetul-indžabi fi davil-islami, riječi Abdurrahmana Abdul-Halika, str. 111. Preuzeto iz: Nasir el-Mejmani, En-Nevazilut-tibbijje, str. 161. 
Na ovaj dokaz može se odgovoriti time da je dozvola uvjetovana sigurnošću da ne dođe do miješanja sjemena. ${ }^{40}$

\section{Šesti dokaz:}

Za odabir spola neophodno je otkrivanje stidnog mjesta što se ne dozvoljava radi ostvarenja želje roditelja. ${ }^{41}$

$\mathrm{Na}$ ovaj dokaz se može odgovoriti time da je dozvola uvjetovana postojanjem darure - prijeke potrebe ili velike potrebe koja poprima propis darure, a darura dozvoljava zabranjeno u mjeri koja je neophodna. ${ }^{42}$

\section{Rezime:}

Nakon što smo upoznali metode određivanja spola djeteta, te vidjeli dokaze oba mišljenja i odgovore na njih, zaključujemo slijedeće:

1. Odabir spola djeteta metodom abortiranja neželjenog spola je zabranjen, jer su učenjaci konsenzusom složni da je abortus haram nakon što se udahne duša u embrion ${ }^{43}$, dok po pitanju abortiranja prije udisanja duše učenjaci imaju različita mišljenja, a preferira se zabrana abortusa čak i prije udisanja duše, osim u izuzetnim slučajevima kada za tim postoji, po Šerijatu, validno opravdanje. ${ }^{44}$

2. Što se tiče prirodnih metoda odabira spola djeteta, možemo primijetiti da se većina dokaza zabrane ne odnosi na te metode, jer $\mathrm{u}$ njima nema uplitanja medicinara, nego se ostvaruju između samih bračnih parova. Na te metode se mogu odnositi dokazi koji se baziraju na tvrdnji da je odabir spola uplitanje u Allahovu volju i odredbu, a već je ranije odbijena ovakva tvrdnja. Prema tome, ove metode su dozvoljene, ukoliko ne uzrokuju nešto što je vjerom zabranjeno, kao što je oslanjanje na njih uz zaborav Uzroka svih uzroka: Uzvišenog Allaha.

\footnotetext{
${ }^{40}$ Nasir el-Mejmani, En-Nevazilut-tibbijje, str. 162.

41 Abdur-Rešid Kasim, Ibtijaru ď̌insil-ď̌enin diraseten fikhije tibbijje, str. 71. Preuzeto iz: Nasir el-Mejmani, En-Nevazilut-tibbijje, str. 161.

42 Nasir el-Mejmani, En-Nevarilut-tibbijje, str. 162.

43 El-Mevsuatul-fikbijetul-Kuvejtije, 2/56.

44 Dr. Muhammed Osman Subejr, Mevkiful-islami minel-emradil-virasijjeti, zbirka elaborata: Dirasatun fikbijetun fi kadaja tibbijje muasire, 1/345, i Nasir el-Mejmani, En-Nevarilut-tibbijje, str. 163.
} 
Uvjet je da se čvrsto vjeruje da su to samo uzroci, koji će dati rezultat ako to Allah želi, a sve je, na početku i na kraju, Allahova odredba.

3. Mišljenje da su laboratorijske metode, kada se za to ispune potrebni uvjeti, dozvoljene i šerijatski legitimne, preferirajuće je zbog jačine navedenih argumenata i mogućnosti odgovora na dokaze drugog mišljenja, a Uzvišeni Allah najbolje zna.

\section{Uslovi dozvole su slijedeći:}

- da se laboratorijskoj metodi pristupi samo u slučaju darure - prijeke potrebe ili velike potrebe koja uzima propis darure,

- da zahvat bude izveden od strane pouzdanog ljekara muslimana, koji će udovoljiti želji roditelja, tek nakon što se uvjeri da za tim postoji stvarna potreba,

- da odabir spola djeteta ne obuhvati širok dijapazon ljudi, nego da ostane u uskim granicama i na nivou pojedinaca,

- da se vjeruje da sve što čovjek čini samo je uzrok, a krajnji rezultat je u Allahovoj ruci, On određuje šta želi i poklanja mušku i žensku djecu kome On hoće,

- da se ispune uslovi dozvole vještačke oplodnje, tj. da nakon što se ustanovi stvarna potreba za vještačkom oplodnjom, da se provjeri postojanje ispravne bračne veze između para koji želi dijete, da prevlada mišljenje ljekara da će oplodnja uspjeti, da se preduzmu sve moguće i potrebne mjere da ne dođe do miješanja sjemena, kao što su: da se oplodnja učini odmah u prisustvu muža, da se uništi sjeme koje preostane nakon oplodnje i da se operacija izvede u zvaničnim centrima u kojima je sigurno da neće doći do miješanja sjemena. Također, obavezno je pridržavati se općih propisa o otkrivanju stidnog mjesta, tj. da se otkrije samo u mjeri koja je neophodna, te da ljekar bude žena muslimanka, a ako ne, onda pouzdana nemuslimanka, zatim pouzdan musliman, te pouzdan nemusliman i da ne dođe do osamljivanja. ${ }^{45}$

45 Abbas el-Baz, elaborat pod naslovom: Ibtijaru ď̌insil-mevludi, zbirka elaborata: Dirasatun fikbijetun fi kadaja tibbijje muasire, 2/880, i Nasir el-Mejmani, En-Nevaziluttibbijje, str. 163. 


\section{Zaključak}

Iz riječi Poslanika, sallallahu alejhi ve sellem, razumije se da na spol novorođenčeta utječu oba roditelja, a savremena znanost je to naučno objasnila.

Savremena medicina potvrdila je da muško sjeme nosi spermatozoide tipa y koji nose oznake muškog spola i spermatozoide tipa x koji nose oznake ženskog spola i da se spol djeteta određuje već kod prvog spoja određenog tipa spermatozoida s jajnom ćelijom, a na to ukazuju kur'ansko-hadiski tekstovi.

Ne postoji oprečnost između našeg vjerovanja izgrađenog na ajetima i hadisima, koji potvrđuju da Uzvišeni Allah zna šta je u maternicama i da kome On želi poklanja mušku ili žensku djecu, i mogućnosti spoznaje spola djeteta prije rođenja i utjecaja na vrstu spola.

Postoje brojne metode kojima se odabire spol djeteta, neke su prirodne, poput vremenskog reguliranje snošaja i konzumiranja određene hrane, a druge su laboratorijske, poput oplodnje po odabiru. Te metode su različite u stepenu i procentu uspješnosti.

Prirodne metode su dozvoljene uz uslov da se ne oslanja na njih, nego da se čvrsto vjeruje da su to samo uzroci koji će dati rezultat ako to Allah želi, i da je stvar, na početku i na kraju, u Allahovoj ruci.

Ukoliko postoji prijeka potreba (darura) ili velika potreba koja poprima propis darure, laboratorijski odabir spola djeteta je dozvoljen, ali je dozvola ograničena uslovima i pravilima koji dozvolu svode samo na posebna stanja i sprječavaju neželjene posljedice.

Uzvišeni Allah najbolje zna. Njemu hvala na početku i na kraju. Neka su salavati i selami na Allahovog miljenika, odabranog roba i poslanika, Muhammeda, njegovu porodicu, ashabe i sve koji slijede njegovu uputu.

\section{Literatura:}

1. Abdurrahman bin Ebi Bekr Dželalud-din es-Sujuti: El-Ešbahu ven-nezair, Darulkutubil-ilmije, Libanon, prvo izdanje, 1983.

2. Ebu Abdullah Muhammed bin Ahmed el-Kurtubi: El-Džami'u li abkamil-Kur'ani, Darul-kutubil-misrije, drugo izdanje, Kairo, 1384. h. g.

3. Ebul-Feda Ismail bin Omer bin Kesir: Tefsirul-Kur'anil-azim, obrada: Sami bin Muhammed Selame, Daru Taibe lin-nešri vet-tevzi, drugo izdanje, 1420. h. g. 
4. Ebul-Hasan bin Muhammed el-Maverdi: En-Nuketu vel-'ujun, Darul-kutubil-ilmije, Bejrut-Libanon, obrada: Es-Seid ibn Abdul-Maksud.

5. El-I'ad乏̌azul-'ilmij, naučni časopis, br. 29, izdavač: Svjetski kolegij za naučne mudžize (nadnaravnost) u Kur'anu i sunnetu, safer 1429. h.g .

6. El-Mevsuatul-arebijjetul-alemijje (Arapska svjetska enciklopedija), izdavač: Organizacija za pripremu enciklopedije, drugo izdanje.

7. El-Mevsuatul-fikhijetul-Kuvejtije, izdavač: Ministarstvo vakufa i vjerskih pitanja, Kuvajt, 1404. - 1407. h. g.

8. Fetava El-Led乏̌netid-daime, el-medžmuatul-ula ves-sanije, sabrao: Ahmed bin Abdurrezak ed-Duvejš.

9. Muhammed el-Bar: Halkul-insani bejnet-tibbi vel-Kur'ani, Darus-Saudije, Džidda, sedmo izdanje, 1409. h. g.

10. Muhammed bin Ismail el-Buhari: Sabibul-Buhari (Buharijeva zbirka hadisa), DarušŠuab, Kairo, prvo izdanje, 1987.

11. Muslim bin el-Hadždžadž en-Nejsaburi: Sahibu Muslim (Muslimova zbirka hadisa), Daru ihjait-turasil-arabij, Bejrut, obrada: Muhammed Fuad, Abdul-Baki.

12. Nasir el-Mejmani: En-Nevaz̧ilut-tibbijje, Daru-ibnul-Dževzi, Demam, Saudijska Arabija, prvo izdanje, 1430. h. g.

13. Omer Sulejman el-Eškar, Muhammed Osman Šubejr, Abdun-Nasir ebul-Besal, Arif Ali Hidžazi i Abbas Ahmed el-Baz: Dirasatun fikbijetun fi kadaja tibbijje muasire, Darun-nefais, Jordan, prvo izdanje, 1421. h. g.

14. Zejnul-abidin bin Nudžejm: El-Ešbabu ven-nez̧air ala mez̧hebi Ebi Hanifeten-Nu'man, Darul-kutubil-ilmije, Libanon, 1980. 


\section{GENDER SELECTION OF EMBRYO THROUGH THE PRISM OF SHARIAH}

\section{ABSTRACT}

Modern lifestyle and technical achievements initiated many questions that were not considered by classical Islamic jurists. The Qur'an, the last Revelation of God, and the Sunnah, the sayings and actions of the Prophet, sallallaabu alaybi wa sallam, as the fundamental sources of Islamic faith, directly or indirectly contain judgments about all the innovations and trends that will happen until the Day of Judgment.

In order to recognize Sharia regulations regarding these phenomena, we can clearly see the divine light and perfect knowledge through the Quranic verses and words of the Prophet, sallallaahu alayhi wa sallam, who does not speak of his whim. They are in perfect conformity with modern knowledge and scientific discoveries even though they were expressed at the time when human knowledge was at a very low level,.

Formation of embryo gender, like everything else in nature that surrounds us, is regulated by the law which were established by Allah. Modern man discovered details of that law, which had previously been unknown to humankind. That opened the possibility of influencing the sex of the embryo. On the other hand, the believer knows that Allah is the One who creates and selects and to Whom everything returns. He is the One who gives to whom He wants male and female children and He leaves some without offspring. Therefore, the issue of gender selection of embryo are studied from the aspect of Islamic doctrine - aqidah that treats beliefs and convictions of Muslims, and the aspect of Islamic jurisprudence - fiqh, which treats the practical side, or acts and practices in Islam.

Methods of gender selection are numerous and their regulations are different. Islamic scholars have expressed their opinions on them, which shall be shown in this paper, by Allab's permission.

Keywords: gender, child, seed, embryo, selection, male, female, methods . 


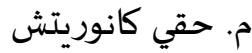

\section{اختيار جنس الجنين من منظور الشريعة الإسلامية}

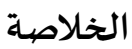

أسلوب الحياة المعاصرة ومكتشفات التقنيات المعاصرة أثاروا الكثير من المسائل

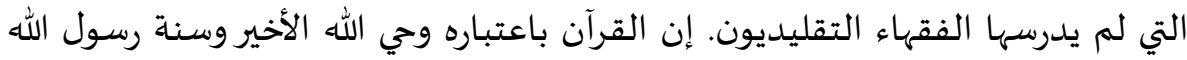

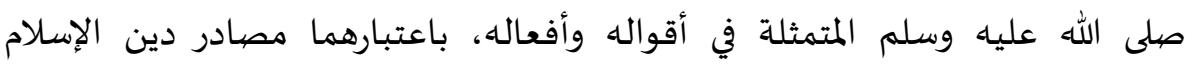

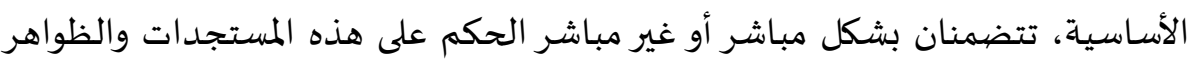

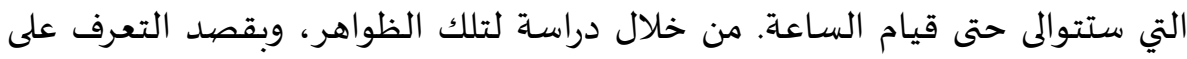

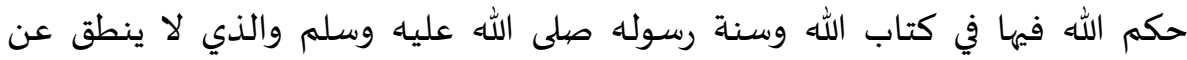

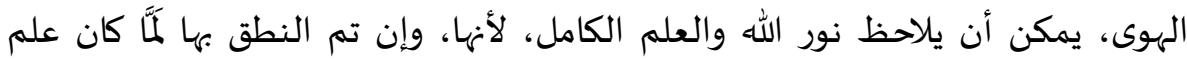

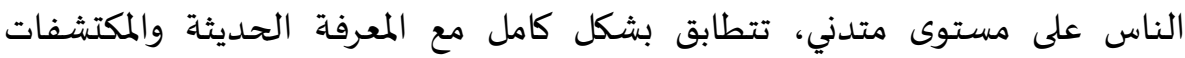

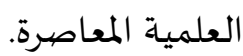

تكوين جنس الجنين، مثل كل ما يحيط بنا في الطبيعة، يحدث وفق قانون



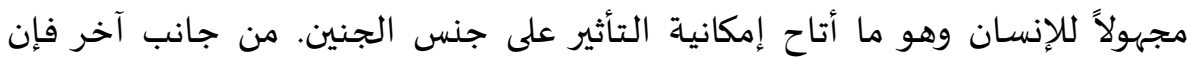

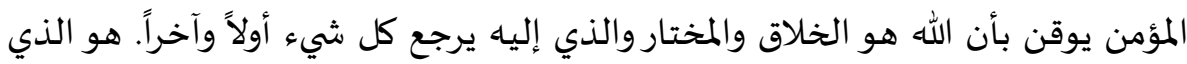

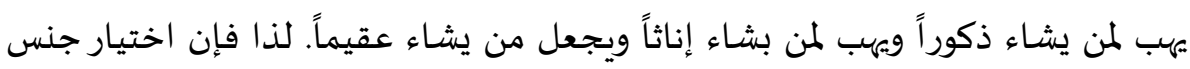

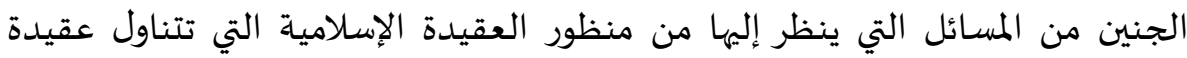

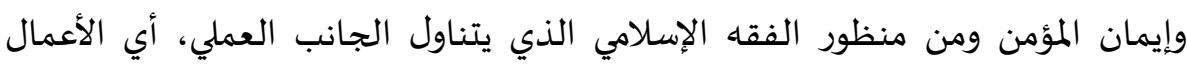
والتصرفات.

إن أساليب اختيار جنس الجنين عديدة وتختلف أحكامها وقد عرض كبار الفقهاء آراءهم حولها كما سيأتي بيانه خلال هذا البحث البحن بإذن الله.

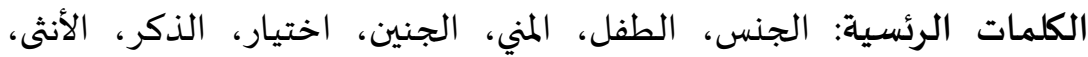

